University of Nebraska - Lincoln

DigitalCommons@University of Nebraska - Lincoln

Virology Papers

Virology, Nebraska Center for

August 1998

Cytoplasmic Assembly and Accumulation of Human

Immunodeficiency Virus Types 1 and 2 in Recombinant Human

Colony-Stimulating Factor-1-Treated Human Monocytes: An

Ultrastructural Study

Jan Marc Orenstein

George Washington University Medical Center

Monte S. Meltzer

Walter Reed Army Institute of Research

Terri Phipps

Walter Reed Army Institute of Research

Howard Gendelman

University of Nebraska Medical Center \& Nebraska Center for Virology, hegendel@unmc.edu

Follow this and additional works at: https://digitalcommons.unl.edu/virologypub

Part of the Virology Commons

Orenstein, Jan Marc; Meltzer, Monte S.; Phipps, Terri; and Gendelman, Howard, "Cytoplasmic Assembly and Accumulation of Human Immunodeficiency Virus Types 1 and 2 in Recombinant Human ColonyStimulating Factor-1-Treated Human Monocytes: An Ultrastructural Study" (1998). Virology Papers. 89. https://digitalcommons.unl.edu/virologypub/89

This Article is brought to you for free and open access by the Virology, Nebraska Center for at DigitalCommons@University of Nebraska - Lincoln. It has been accepted for inclusion in Virology Papers by an authorized administrator of DigitalCommons@University of Nebraska - Lincoln. 


\title{
Cytoplasmic Assembly and Accumulation of Human Immunodeficiency Virus Types 1 and 2 in Recombinant Human Colony-Stimulating Factor-1-Treated Human Monocytes: An Ultrastructural Study
}

\author{
JAN MARC ORENSTEIN, ${ }^{1 *}$ MONTE S. MELTZER, ${ }^{2}$ TERRI PHIPPS, ${ }^{2}$ AND HOWARD E. GENDELMAN ${ }^{2,3}$ \\ Department of Pathology, George Washington University Medical Center, 2300 Eye Street, N.W., Washington, D.C. \\ 20036, ${ }^{1}$ Department of Cellular Immunology HIV Immunopathogenesis Program, Walter Reed Army Institute of \\ Research, Washington, D.C. 20307²; and Department of Medicine, Columbia University College of Physicians and \\ Surgeons, New York, New York $10032^{3}$
}

Received 29 December 1987/Accepted 8 April 1988

\begin{abstract}
Recombinant human colony-stimulating factor-1-treated human peripheral blood-derived monocytes-macrophages are efficient host cells for recovery of the human immunodeficiency virus (HIV) from blood leukocytes of patients with acquired immunodeficiency syndrome. These cells can be maintained as viable monolayers for intervals exceeding 3 months. Infection with HIV resulted in virus-induced cytopathic effects, accompanied by relatively high levels of released progeny virus, followed by a prolonged low-level release of virus from morphologically normal cells. In both acutely and chronically infected monocytes, viral particles were seen budding into and accumulating within cytoplasmic vacuoles. The number of intravacuolar virions far exceeded those associated with the plasma membrane, especially in the chronic phase, and were concentrated in the perinuclear Golgi zone. In many instances, the vacuoles were identified as Golgi elements. Fusion of virus-laden vacuoles with primary lysosomes was rare. The pattern of cytoplasmic assembly of virus was observed with both HIV types 1 and 2 and in brain macrophages of an individual with acquired immunodeficiency syndrome encephalopathy. Immunoglobulin-coated gold beads added to acutely infected cultures were segregated from the vacuoles containing virus; relatively few beads and viral particles colocalized. The assembly of HIV virions within vacuoles of macrophages is in contrast to the exclusive surface assembly of HIV by T lymphocytes. Intracytoplasmic virus hidden from immune surveillance in monocytes-macrophages may explain, in part, the persistence of HIV in the infected human host.
\end{abstract}

Human immunodeficiency virus (HIV) is classified as a member of the lentivirus family of retroviruses $(1,15)$. Animal lentiviruses, including visna virus and caprine arthritis-encephalitis virus, predominantly infect mononuclear phagocytes $(3,5,12,22,24-26,30)$. The virus replicates within the immature monocytes at low levels; as the monocytes differentiate into tissue macrophages, viral replication increases several thousand-fold. Accumulation of large numbers of lentiviruses occurs through assembly within cytoplasmic compartments, in some cases identified as rough endoplasmic reticulum $(3,5,14,33,36)$.

Visna virus-infected macrophages have been likened to Trojan horses in that they can enter tissue while harboring virus hidden from host immune surveillance (30). Virus dissemination may occur by passage of infectious particles from the "Trojan horse" to bystander cells through direct contact, cell membrane fusion, or release of progeny virions into the extracellular milieu. The same scenario, with all its implications, can be proposed for HIV. Currently there is no evidence for intracellular assembly and accumulation of infectious HIV within lymphocytes $(18,19,23,29)$. However, preliminary reports indicate that monocytes-macrophages, recently shown to be a major target for HIV infection in the human host $(4,9,17,20,37,39)$, can accumulate virus within cellular compartments $(10,13,28)$.

We recently reported a technique that allows for reproducible isolation of HIV from the leukocytes of seropositive

\footnotetext{
* Corresponding author.
}

patients onto normal human monocytes (13). Such monocyte-tropic HIV is maintained in cultured, blood-derived monocytes for intervals in excess of 40 days and can be serially passaged onto other monocyte cultures from different donors. The purpose of this ultrastructural study was to examine the modes of assembly and accumulation of HIV by monocytes and to determine whether it involves intracellular compartments. In this system, HIV accumulates within cytoplasmic compartments of the monocyte-macrophage and thus is analogous to animal lentiviruses.

\section{MATERIALS AND METHODS}

HIV-infected peripheral blood monocytes. Blood monocytes from normal donors were isolated by countercurrent centrifugal elutriation of peripheral blood mononuclear cellrich fractions (38). Cells were maintained for 7 to 10 days before infection in Dulbecco modified Eagle medium supplemented with $10 \%$ freshly drawn heat-inactivated human serum and 1,000 $\mathrm{U}$ of recombinant macrophage colonystimulating factor-1 (rCSF-1) per $\mathrm{ml}$ as previously described (13). The 120 and Ada isolates of HIV type 1 (HIV-1) previously shown to be tropic for and cytopathic in macrophages were used. Cells were infected with 50,000 reverse transcriptase counts, $10^{2} 50 \%$ tissue culture infectious doses. The HIV-2 ROD isolate was previously described (2). Cells were harvested for transmission electron microscopy at 14 

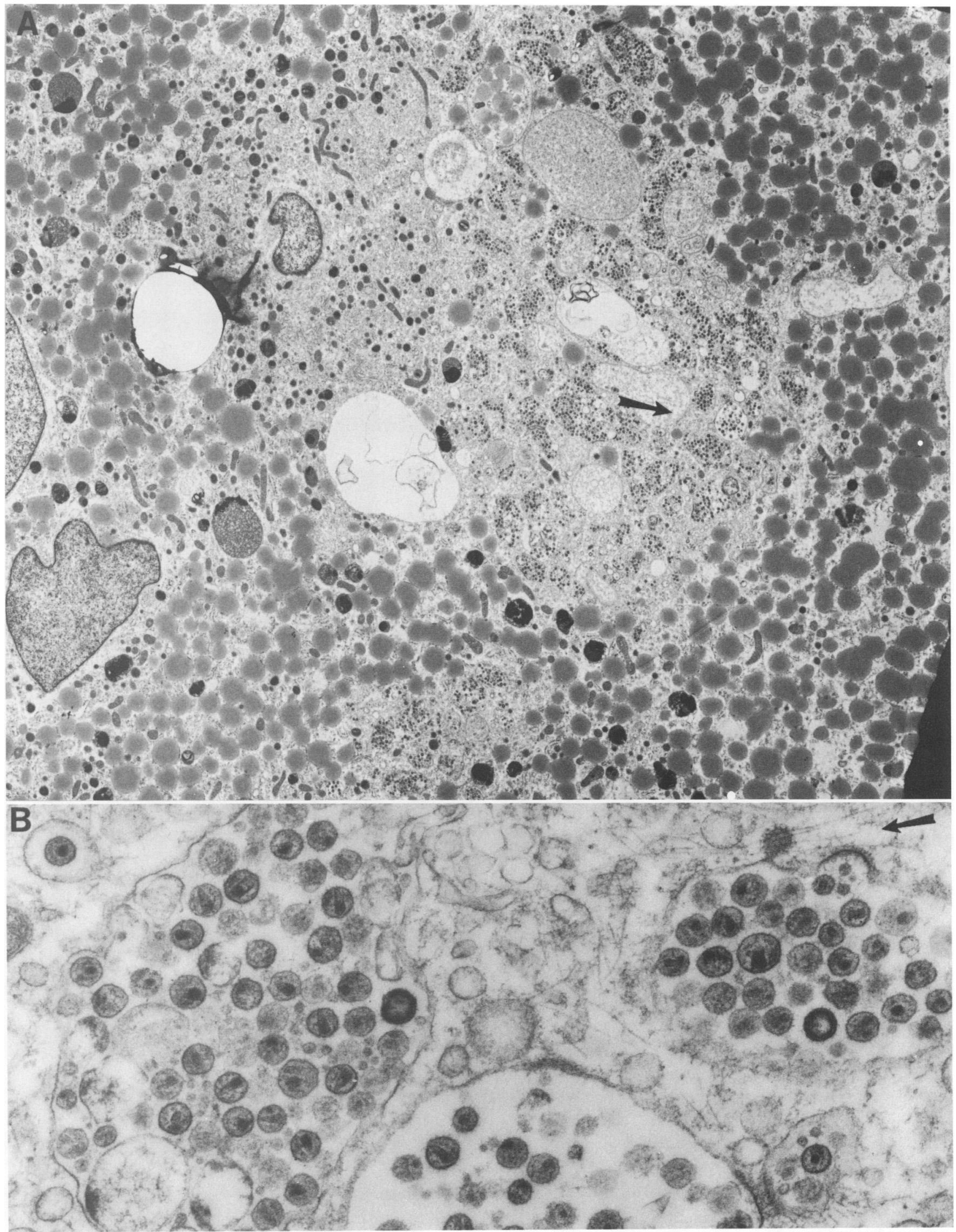

FIG. 1. Part of an HIV-1-intected (day 14) multınucleated cell (A) with scores of pleomorphic cytoplasmic vacuoles laden with mostly mature virions but also containing budding and immature forms ( $B$, enlargement of $A$ at arrow). The vacuoles do not reach the plasma membrane (right edge), which lacks associated particles. Lipid vacuoles and lysosomes surround the vacuoles (A). Coated vesicles are associated with the vacuole membrane (B, arrow). Magnification: A, $\times 4,300 ; B, \times 48,000$. 


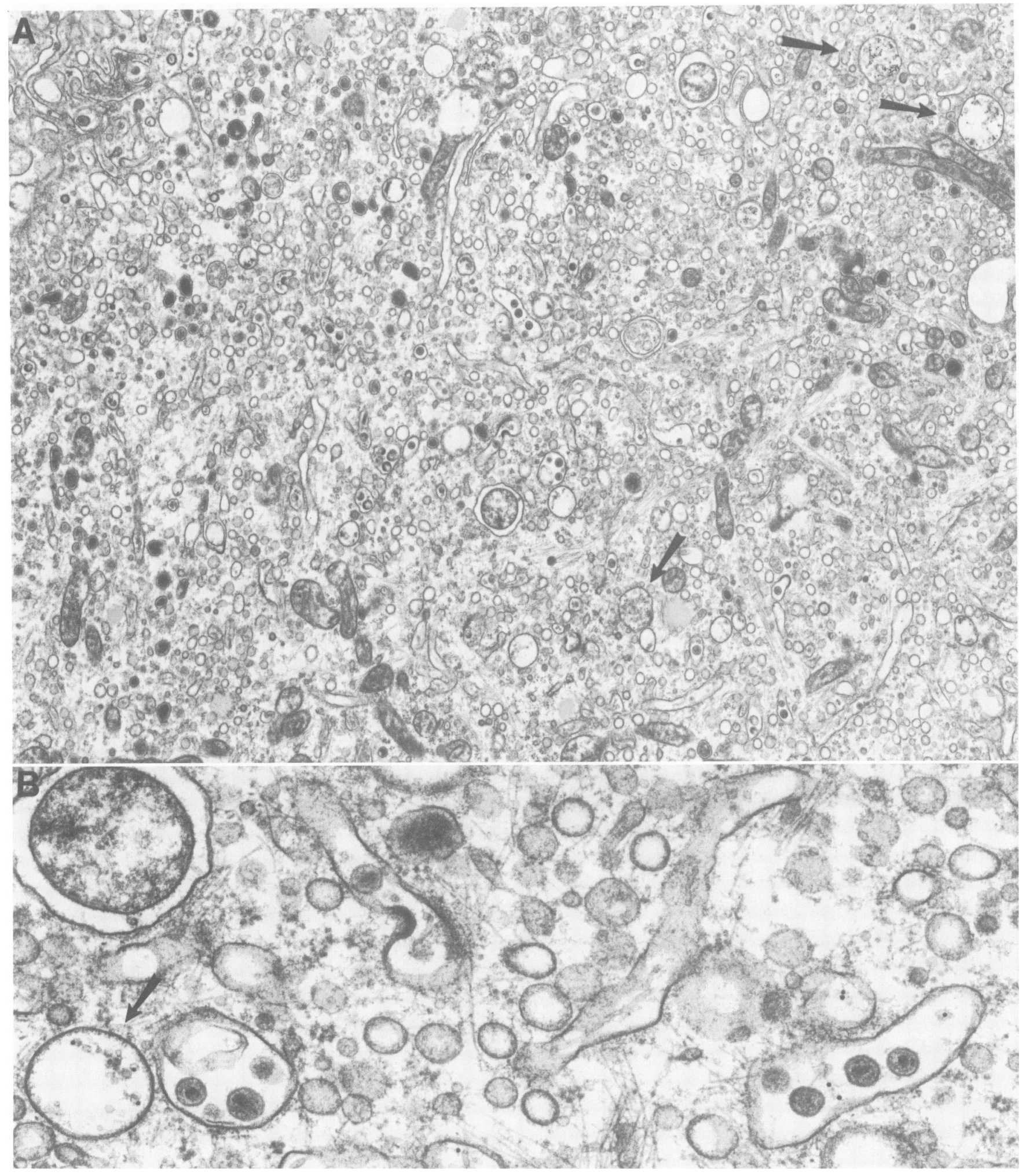

FIG. 2. Central cytoplasm (plasma membrane at upper left) of a macrophage (day 14) (A) laced with small saccules-vacuoles, many containing budding particles and up to four mature particles (B, enlargement of center of A). Few gold beads are in occasional vacuoles (45-min exposure), but most beads are in the larger multivesicular body (arrows). Magnification: A, $\times 12,500 ; B, \times 48,000$. 


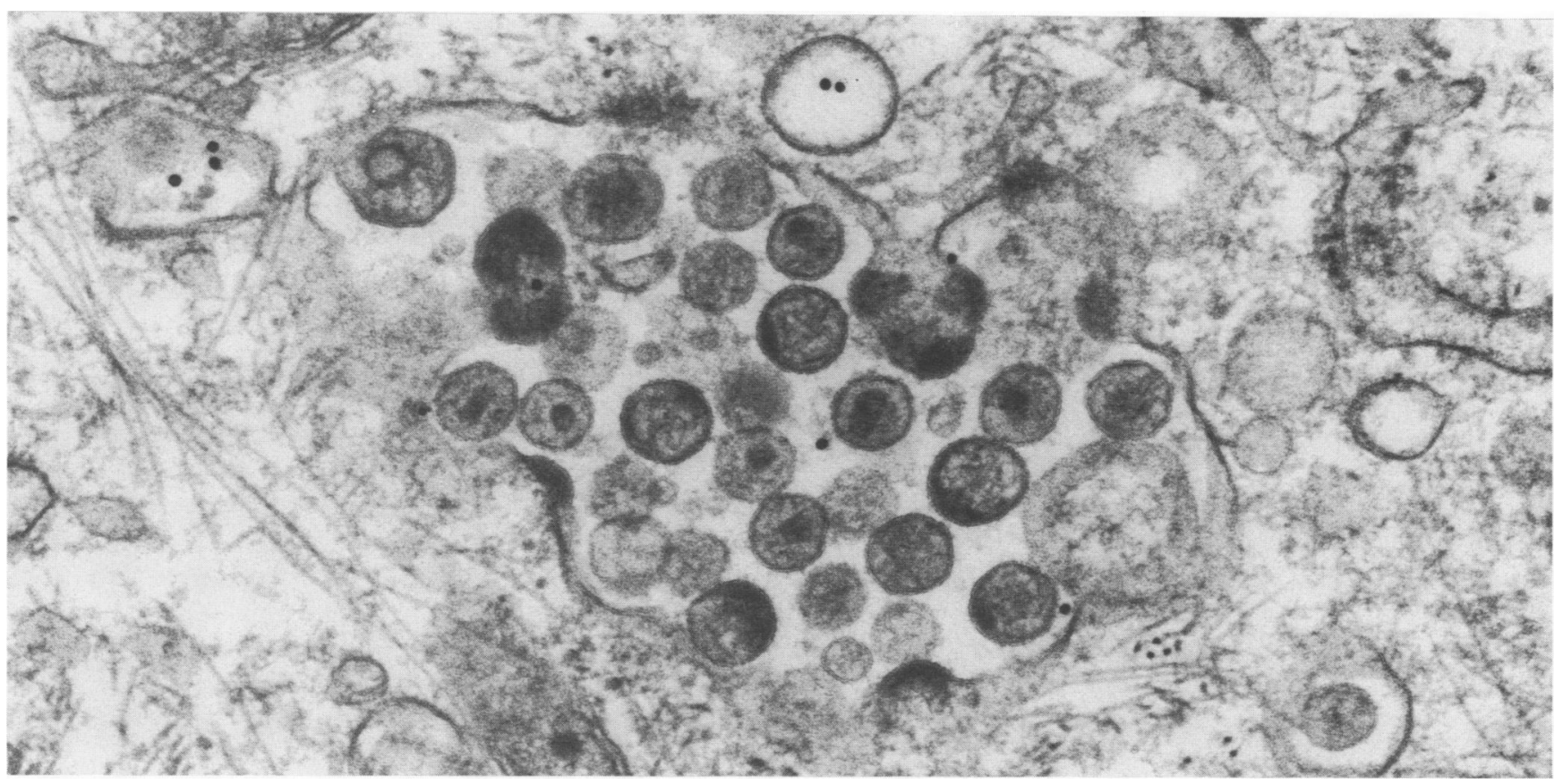

FIG. 3. Two virus-containing vacuoles were seen in the section of a mononuclear macrophage (day 14, HIV-1): one with a single virion and the second, shown here, with several budding and mature particles. Vacuoles carrying gold beads (45-min exposure) appear to be fusing with the main vacuole, serving as the source of its beads. A single virion was seen associated with the surface of the cell. Magnification: $\times 84,000$.

days (during the acute cytopathic infection) and $\mathbf{4 0}$ days (chronic infection).

Preparation for ultrastructural studies. Chronically infected cells were removed from plastic culture wells with a Pasteur pipette (unless designated, all procedures were carried out at room temperature). They were transferred to 15-ml plastic cone-shaped tubes, centrifuged for $10 \mathrm{~min}$ at $600 \times g$, suspended in phosphate-buffered saline, pelleted, and immediately fixed undisturbed with $2.5 \%$ glutaraldehyde in $0.1 \mathrm{M}$ cacodylate buffer $(\mathrm{pH} 7.4)$. The cell pellets were kept in fixative for $1 \mathrm{~h}$ at room temperature and then overnight at $4^{\circ} \mathrm{C}$. The following day, the pellets were fragmented and carefully transferred to $1.5-\mathrm{ml}$ microfuge tubes. After cells were pelleted at $4,500 \times g$ for $2 \mathrm{~min}$, they were processed through $1 \% \mathrm{OsO}_{4}$, for $1 \mathrm{~h}$ in saturated uranyl acetate in $50 \%$ ethanol (block uranyl acetate staining [33]),

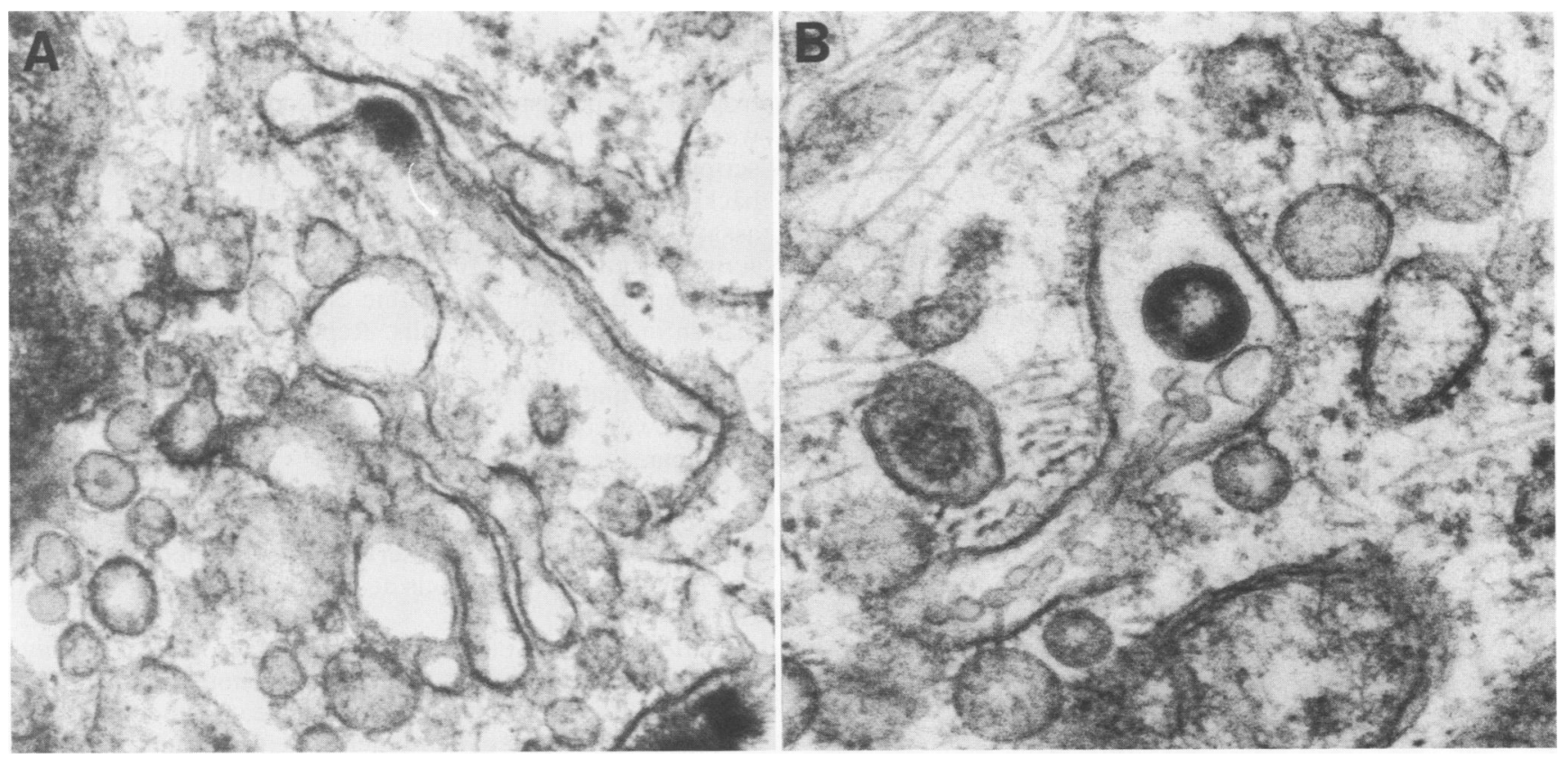

FIG. 4. Viral particles assembling in Golgi saccules-vacuoles (day 14, HIV-1). Magnification: $\times 80,000$. 


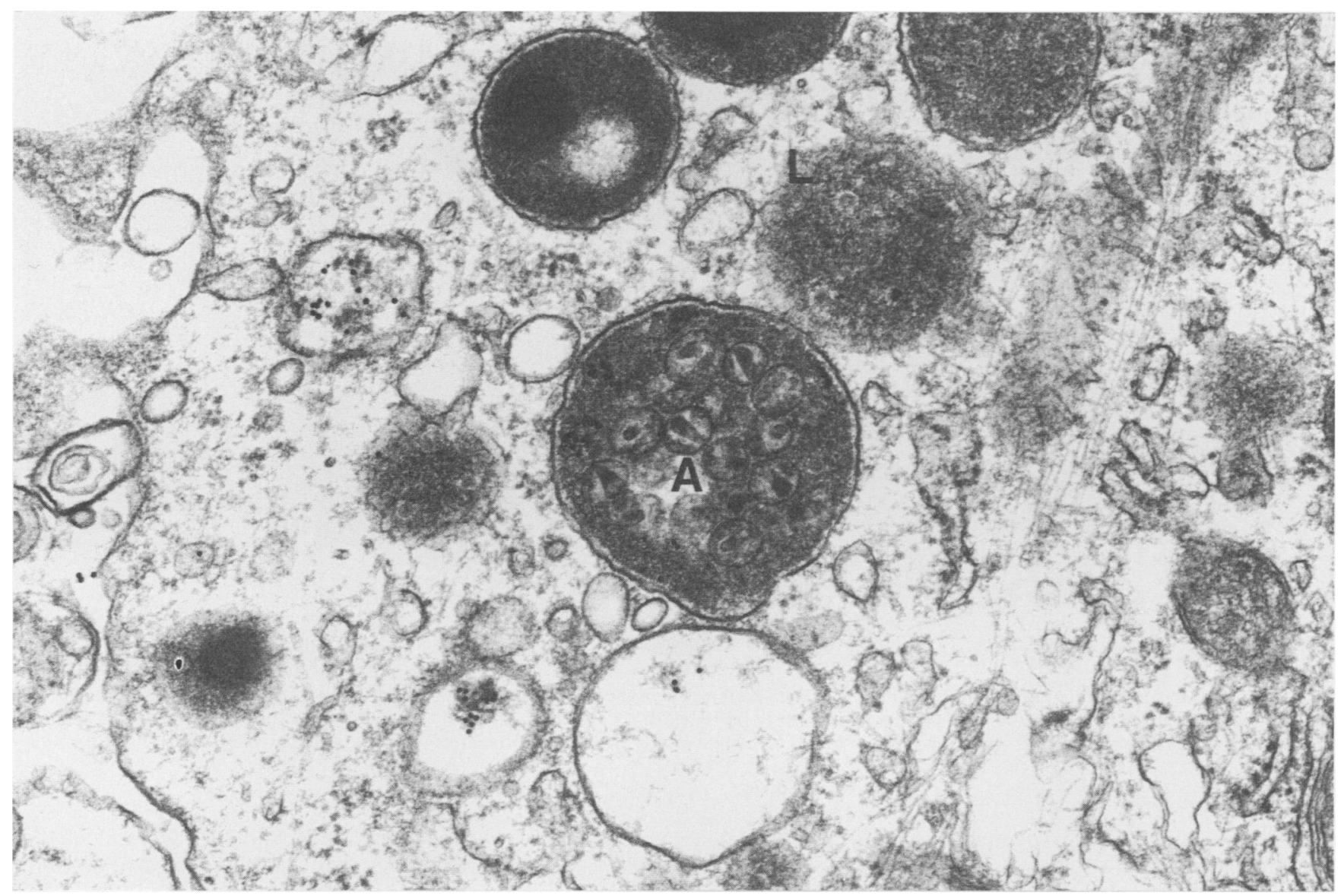

FIG. 5. Gold beads (45-min exposure) are free near the plasma membrane and within clear cytoplasmic vacuoles (endosomes), primary lysosomes (L), and secondary autophagolysosomes (A), which also contains intact mature virions. Magnification: $\times 48,000$.

dehydrated in graded ethanol and propylene oxide, and embedded in Spurr plastic. Thin sections were stained with uranyl acetate and lead citrate and examined on a Zeiss EM $10 \mathrm{~A}^{\mathrm{r}}$ electron microscope.

Exposure to immunoglobulin-coated gold beads. Goat antimouse immunoglobulin G-coated gold beads $(5$ or $15 \mathrm{~nm}$; Janssen, Life Sciences Products, Piscataway, N.J.) were washed by low-speed centrifugation, suspended in $1 \mathrm{ml}$ of culture medium, added to a plastic well (Costar 24; Costar, Cambridge, Mass.) containing $5 \times 10^{5}$ cells 14 days after HIV-1 infection, and incubated for 5 or $45 \mathrm{~min}$. The medium was replaced with glutaraldehyde; after 10 to $15 \mathrm{~min}$ of fixation, the cells were scraped off with a rubber policeman and processed as described above.

Brain biopsy from AIDS patient. A computerized tomography scan-guided biopsy of a brain mass in a 33-year-old homosexual man, subsequently diagnosed with acquired immunodeficiency syndrome (AIDS), was studied by transmission electron and light microscopy after standard processing. Light microscopy revealed only mild astrocytosis (28a).

\section{RESULTS}

HIV-infected monocytes and their viral progeny. Highly purified populations of blood-derived human monocytes (greater than $99.9 \%$ monocytes by immunofluorescence on fluorescence-activated cell sorter flow cytometric analysis) remained viable in culture for over 3 months in medium supplemented with rCSF-1 (13). These cultures provided susceptible target cells for isolation and propagation of virus from blood leukocytes of HIV-infected patients. HIV isolated into such monocytes readily infected other rCSF-1treated monocytes. After several passages of the monocytetropic HIV, persistent, low-level progeny virion production was detected in macrophage culture fluids by reverse transcriptase activity $\left(2 \times 10^{5}\right.$ to $8 \times 10^{5} \mathrm{cpm} / \mathrm{ml}$ versus background of $1 \times 10^{4} \mathrm{cpm} / \mathrm{ml}$ ) or HIV antigen capture assays through 40 days. A transient peak of reverse transcriptase activity $\left(1 \times 10^{6}\right.$ to $\left.3 \times 10^{6} \mathrm{cpm} / \mathrm{ml}\right)$ at 10 to 14 days was coincident with cytopathic changes and giant cell formation in about $25 \%$ of cells. Replicate monocyte cultures without HIV showed no cytopathic changes. By 4 to 6 weeks, virtually all macrophages appeared morphologically normal, with only an occasional multinucleated cell, usually binuclear.

Ultrastructural analysis of HIV-infected, rCSF-1-treated monocytes at 14 days in culture. The ultrastructural morphology of the viral particles observed in the monocyte cultures was consistent with previous descriptions of $\operatorname{HIV}(11,15,23$, 29).

Cell morphology of rCSF-1-treated macrophages 14 days after HIV-1 infection was quite heterogenous. Most macrophages (60 to $80 \%$ ) remained mononuclear, but a significant subpopulation formed multinucleated giant cells (Fig. 1). Degeneration and lysis were observed in both mononuclear 


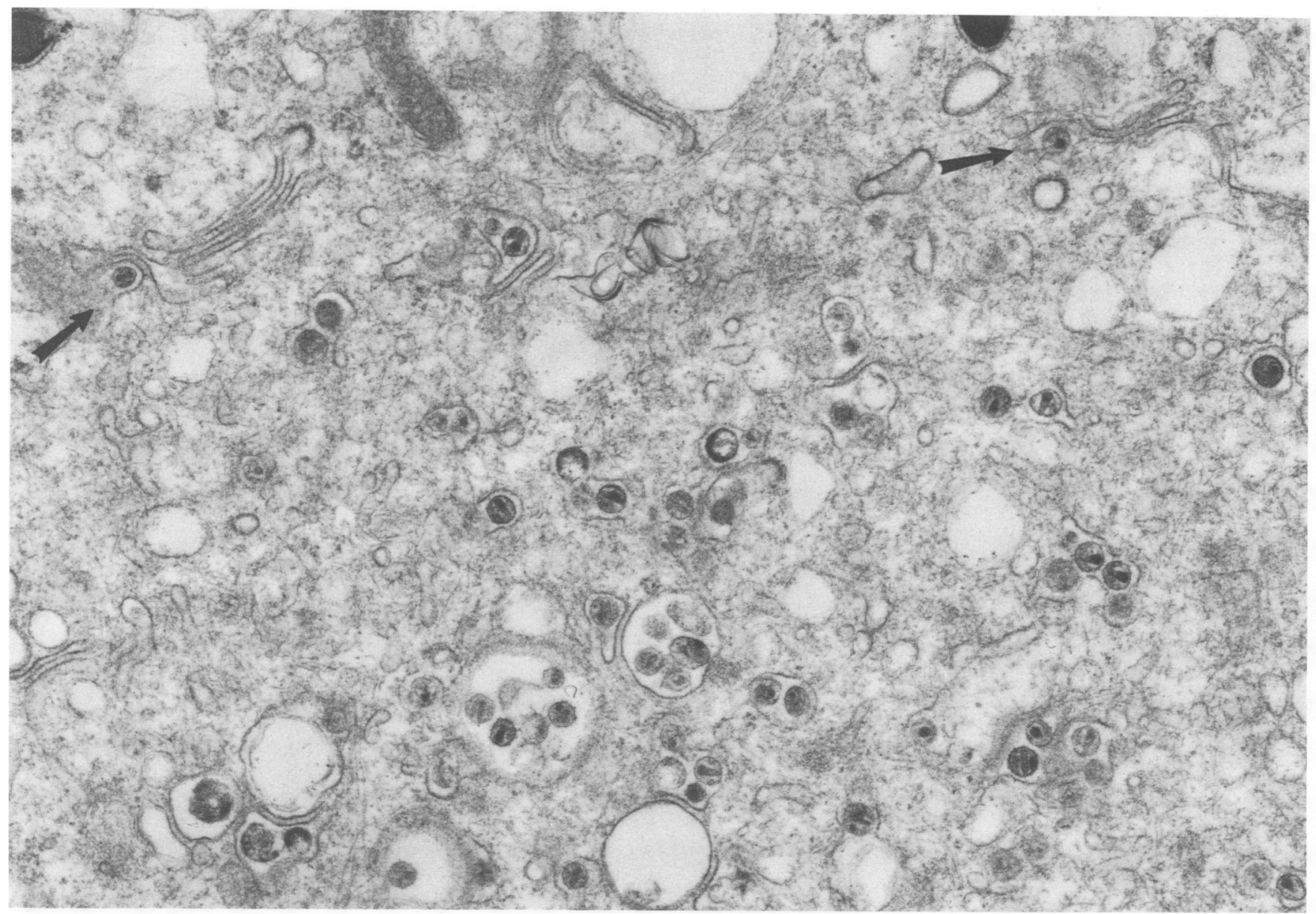

FIG. 6. Perinuclear Golgi zone (day 40, HIV-2) with virions in Golgi saccules-vacuoles (arrows) and vacuoles apparently derived from the Golgi. Magnification: $\times 33,000$.

and multinucleated cells. Degenerative changes included increased numbers of lipid vacuoles and secondary lysosomes and swelling of mitochondria, Golgi elements, and endoplasmic reticulum. Viral budding from the plasma membrane was relatively rare and usually focal. Total plasma membrane-associated virus was relatively sparse ( 0 to 10 particles per cell section). Similar preparations of $T$ cells infected with HIV showed hundreds of viral particles associated with the plasma membrane in a cell section (data not shown) $(11,23,29)$. The largest numbers of apparently free (extracellular) viral particles were observed admixed with cellular debris or associated with cytoplasmic vacuoles undergoing disruption.

The predominant localization of HIV was within cytoplasmic vacuoles (Fig. 1 through 4 ). The largest numbers of vacuoles, about 100 , and numbers of virions per vacuole, also about 100 , were in multinucleated giant cells (Fig. 1). Sections of both mononuclear and multinucleated cells alike could contain as few as a single vacuole with a single virion or numerous vacuoles with up to four virions (Fig. 2). The pleomorphic, predominantly smooth-surfaced, vacuoles contained budding, immature, and especially mature particles. These vacuoles were typically concentrated within the perinuclear Golgi zone, which in multinucleated cells was often surrounded by nuclei (Fig. 1). HIV particles were identified budding into typical Golgi saccules and vacuoles
(Fig. 2 and 4). Some virus-containing vacuoles also had small smooth-walled vesicles, giving them the appearance of Golgi-derived structures termed multivesicular bodies (Fig. 1B). A partial, electron-dense coating was seen on some vacuoles (Fig. 1B and 2B). Apparent instarices of fusion between cytoplasmic vacuoles, with and without enclosed virus, were common (Fig. 1B, 2B, and 4B). However, examples of fusion between the numerous lysosomes and virus-laden cytoplasmic vacuoles were rare (Fig. 5). Nevertheless, HIV-infected macrophages undergoing degeneration or actual lysis often showed large numbers of secondäry lysosomes (autophagosomes) filled with mature virions, only some of which were aberrant (probably degenerative). Remarkably, some of these secondary lysosomes contained budding virions.

Ultrastructural analysis of $\mathrm{HIV}$-infected, rCSF-1-treated monocytes at $\mathbf{4 0}$ days in culture. Monocyte cultures treated with rCSF-1 and infected for $\mathbf{4 0}$ days with HIV-1 or HIV-2 showed minimal degeneration and necrosis. Viral particles were associated with 10 to $15 \%$ of macrophage cell sections. In each case, progeny virions were predominantly localized within cytoplasmic vacuoles and not the plasma membrane (Fig. 6). In the HIV-2-infected macrophages, only a single plasma membrane-budding virion was detected in a sampling of 50 consecutively analyzed sections of cells.

As in the acutely infected cells, the virus-containing 


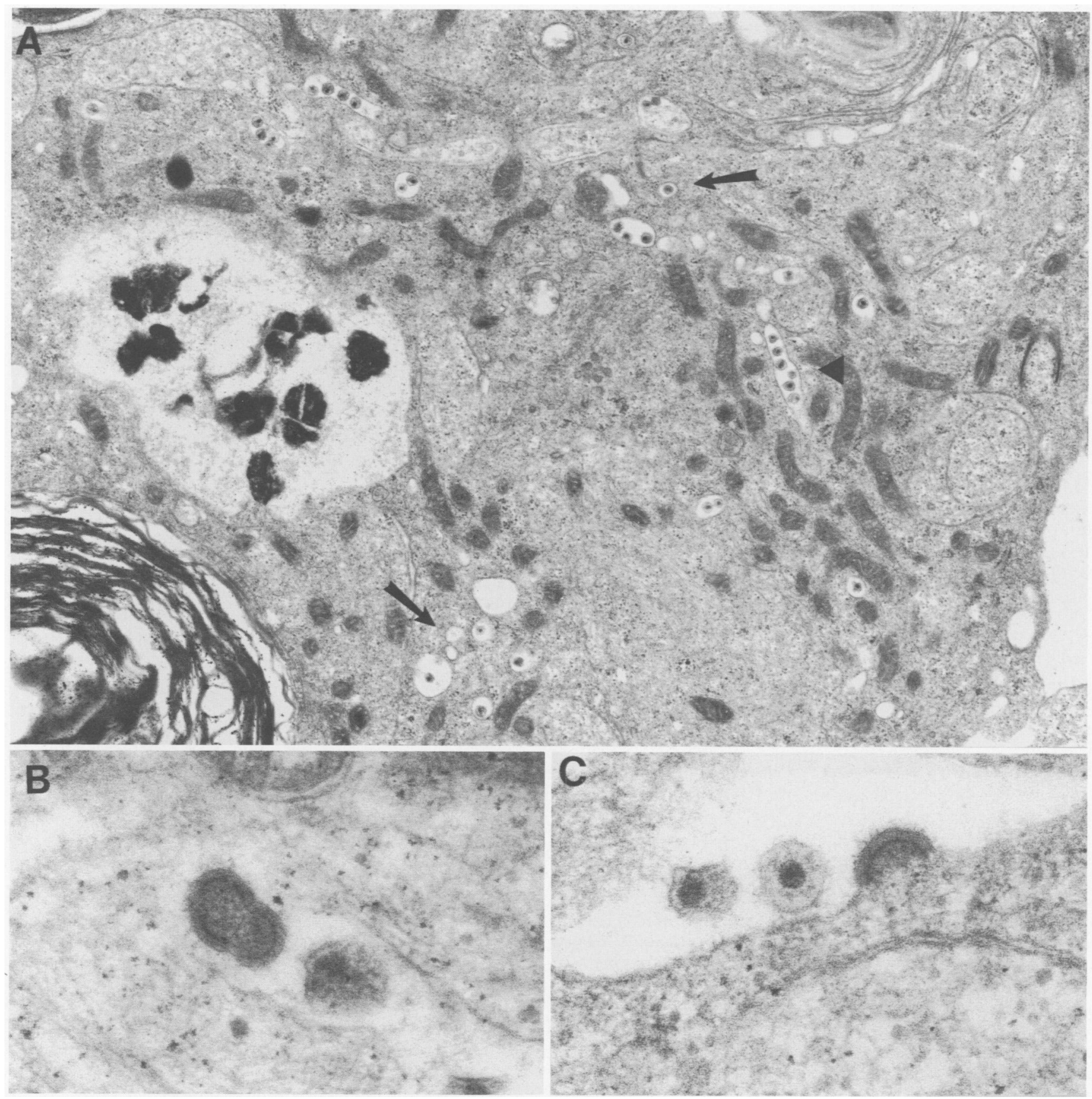

FIG. 7. Part of a central nervous system macrophage (A) containing phagocytized myelin and debris and numerous clear cytoplasmic vacuoles with from one (arrows) to six (arrowhead) mature virions. Two other sections of central nervous system macrophages show a mature and double budding particle in a cytoplasmic vacuole (B) and a budding and two mature particles at the plasma membrane (C). Magnification: A, $\times 16,000 ; B$ and C, $\times 109,000$.

vacuoles were often clearly identified as Golgi elements (Fig. 6). Likewise, some vacuoles resembled multivesicular bodies and/or exhibited a partial electron-dense coating but were never associated with ribosomes and thus did not appear to represent dilated profiles of rough endoplasmic reticulum.

Exposure of 14-day infected cells to immunoglobulin-coated gold beads. Immunoglobulin (rabbit anti-mouse immunoglobulin G)-coated 5- or 15-nm gold beads were added to HIVinfected monocyte cultures at 14 days to determine whether any of the virus-laden vacuoles represented endosomes. After 5 and 45 min of exposure, numerous gold beads were identified within coated pits, pinocytic vesicles and vacuoles, or endosomes. Spherical endosomes about $400 \mathrm{~nm}$ in diameter with gold beads were especially numerous near the cell surface (Fig. 2 and 5). No viral particles were observed being endocytized with or without gold beads. An occasional cytoplasmic vacuole near the plasma membrane contained gold beads as well as virus (Fig. 3). However, the overwhelming number of vacuoles with gold beads (presumed endosomes) had no virus (Fig. 2 and 5).

Localization of HIV within macrophages in the central nervous system of an AIDS patient. To determine whether the 
patterns of virus assembly and accumulation that were observed in vitro were present in HIV-infected individuals, a brain biopsy specimen from a patient with AIDS encephalopathy was examined (Fig. 7). As in vitro, macrophages showed cytoplasmic vacuoles with one to several mature particles and occasional immature particles. The vacuoles were distributed from the central perinuclear cytoplasm to the subplasmalemma and were generally empty save for the virus. Some of the vacuoles had a partial electron-dense coating.

\section{DISCUSSION}

Ultrastructural analysis of HIV interactions with rCSF-1treated human monocytes documented the following sequence of events. After exposure to monocyte-tropic variants of HIV, rCSF-1-treated monocytes entered into an acute phase of infection at about 10 to 14 days that was characterized by relatively high levels of released virions and cytopathic changes. After this acute wave, little progeny HIV was released into culture supernatants despite continued high frequencies of infected cells ( 60 to $80 \%$ by fluorescence-activated cell sorting and in situ hybridization) (13). This apparent discrepancy between the levels of released and synthesized virus was explained by the observation that during the chronic phase monocytes manufactured and sequestered virus predominantly within cytoplasmic compartments, as opposed to both intracytoplasmic and plasma membrane assembly in the acute phase. The intracytoplasmic site of assembly of virus progeny was associated with elements of the Golgi apparatus. Cell sections through infected monocytes often revealed hundreds of viral particles within equally numerous intracytoplasmic vacuoles. These findings suggest that the initial peak of reverse transcriptase activity reflects both the release of intravacuolar virus through cell lysis and the release of virus from the plasma membrane, which appears to be the exclusive site of assembly for HIV-infected, phytohemagglutinin-stimulated lymphoblasts and T-cell lines $(18,19,23)$. The ultrastructural changes we have described in this report are consistent with and further support the hypothesis that mononuclear phagocytes are reservoirs for HIV during both acute and chronic phases of infection.

The site of virus assembly in the macrophages was strongly associated with the Golgi. The vacuoles containing assembling virus were concentrated in the perinuclear region and resembled the condensing vacuoles formed on the trans face of Golgi $(7,8,16,35)$. Assembly was also seen in typical Golgi saccules. Portions of Golgi cisternae can be clathrin coated, as can be parts of condensing vacuoles or granules, and coated vesicles can be seen either budding from or fusing with condensing vacuoles. This could explain the partial coating on some of the virus-laden vacuoles. Since no endocytosis of virus was discerned, it would appear that virus-containing vacuoles acquired their gold beads by fusion with endocytic vesicles (8).

An abundance of primary lysosomes is characteristic of macrophages, yet remarkable was the relative rarity of fusion products, i.e., secondary lysosomes, between virusladen vacuoles and primary lysosomes. HIV could inhibit lysosomal fusion in a manner analogous to that of certain bacterial and parasitic organisms (21).

The clinical consequences of long-term macrophage infection are manifold. These cells may be the initial infected cell in humans and the conduit for T-cell infection and destruction (31). HIV infection of macrophages can also explain defects in antigen presentation and cytokine production. The latter could result in such clinical sequelae as slim disease (34) mediated by an altered release of tumor necrosis factor (32). Infected macrophages may also play prominent roles in the development of the encephalopathy associated with AIDS. Factors secreted by infected macrophages could result in the impairment of neuronal-glial function and/or in central nervous system inflammatory response to HIV. In this regard, infection in primary central nervous system cells per se may have little to do with the pathogenesis of the AIDS dementia complex $(6,27)$. Last, one must consider combating a persistent HIV macrophage infection in drug therapeutics and development. The ultimate development of effective chemotherapeutics for AIDS may reside in destruction of the reservoirs of infected cells, the HIV-infected monocytes-macrophages.

\section{ACKNOWLEDGMENTS}

We gratefully acknowledge the expert technical assistance of Marianna Rockis and Seth Honig.

H. E. Gendelman is a Carter-Wallace fellow of Columbia University College of Physicians and Surgeons.

\section{LITERATURE CITED}

1. Bouillant, A. M. P., and S. A. W. E. Becker. 1984. Ultrastructural comparison of oncovirinae (type C), spumavirinae, and lentivirinae: three subfamilies of retroviridae found in farm animals. J. Natl. Cancer Inst. 72:1075-1084.

2. Clavel, F., D. Guetard, F. Brun-Vezinet, S. Chamaret, M.-A. Rey, M. O. Santos-Ferreira, A. G. Laurent, C. Dauguet, C. Katlama, C. Rouzioux, D. Klatzmann, J. L. Champalimaud, and L. Montagnier. 1986. Isolation of a new human retrovirus from West African patients with AIDS. Science 233:343-346.

3. Crawford, T. B., D. S. Adams, W. P. Cheevers, and L. C. Cork. 1980. Chronic arthritis in goats caused by a retrovirus. Science 207:997-999.

4. Crowe, S., J. Mills, and M. S. McGrath. 1987. Quantitative immunocytofluorographic analysis of CD4 surface antigen expression and HIV infection of human peripheral blood monocyte/macrophages. AIDS Res. Hum. Retroviruses 3:135-145.

5. Dahlberg, J. E., J. M. Gaskin, and K. Perk. 1981. Morphological and immunological comparison of caprine arthritis encephalitis and ovine progressive pneumonia viruses. J. Virol. 39:914-919.

6. Dewhurst, S., K. Sakai, J. Bresser, M. Stevenson, M. J. EvingerHodges, and D. J. Volsky. 1987. Persistent productive infection of human glial cells by human immunodeficiency virus (HIV) and by infectious molecular clones of HIV. J. Virol. 61:3774 3782.

7. Farquhar, M. G., and G. E. Palade. 1981. The Golgi apparatus (complex)-(1954-1981)-from artifact to center stage. J. Cell Biol. 91:77s-103s.

8. Friend, D. S. 1969. Cytochemical staining of multivesicular body and Golgi vesicles. J. Cell Biol. 41:269-279.

9. Gartner, S., P. Markovits, D. M. Markovitz, R. F. Betts, and M. Popovic. 1986. Virus isolation from and identification of HTLVIII/LAV-producing cells in brain tissue from a patient with AIDS. J. Am. Med. Assoc. 256:2365-2371.

10. Gartner, S., P. Markovits, D. M. Markovitz, M. H. Kaplan, R. C. Gallo, and M. Popovic. 1986. The role of mononuclear phagocytes in HTLV-III/LAV infection. Science 233:215-219.

11. Gelderblom, H. R., E. H. S. Hausmann, M. Ozel, G. Pauli, and M. A. Koch. 1987. Fine structure of human immunodeficiency virus (HIV) and immunolocalization of structural proteins. Virology 156:171-176.

12. Gendelman, H. E., O. Narayan, S. Kennedy-Stoskopf, P. G. E. Kennedy, Z. Ghotbi, J. E. Clements, J. Stanley, and G. Pezeshkpour. 1986. Tropism of sheep lentiviruses for monocytes: susceptibility to infection and virus gene expression increase during maturation of monocytes to macrophages. J. Virol. 58:67-74.

13. Gendelman, H. E., J. M. Orenstein, M. A. Martin, C. Ferrua, R. 
Mitra, T. Phipps, L. A. Wahl, H. C. Lane, A. S. Fauci, D. E. Burke, D. Skillman, and M. S. Meltzer. 1988. Efficient isolation and propagation of human immunodeficiency virus on rCSF-1 treated monocytes. J. Exp. Med. 167:1428-1441.

14. Gonda, M. A., H. P. Charman, J. L. Walker, and L. Coggins. 1978. Scanning and transmission electron microscopic study of equine infectious anemia virus. Am. J. Vet. Res. 39:731-740.

15. Gonda, M. A., F. Wong-Staal, R. C. Gallo, J. E. Clements, 0. Narayan, and R. V. Gilden. 1985. Sequence homology and morphologic similarity of HTLV-III and visna virus, a pathogenic lentivirus. Science 227:173-177.

16. Griffiths, G., and K. Simons. 1986. The trans golgi network: sorting at the exit site of the Golgi complex. Science 234:438443.

17. Ho, D. D., T. R. Rota, and M. S. Hirsch. 1986. Infection of monocyte/macrophages by human $\mathrm{T}$ lymphotropic virus type III. J. Clin. Invest. 77:1712-1715.

18. Hoxie, J. A., B. S. Haggarty, J. L. Rackowski, N. Pillsbury, and J. A. Levy. 1985. Persistent noncytopathic infection of normal human T lymphocytes with AIDS-associated retrovirus. Science 229:1400-1402.

19. Klatzmann, D., F. Barre-Sinoussi, M. T. Nugeyre, C. Dauget, E. Vilmer, C. Griscelli, F. Brun-Vezinet, C. Rouzioux, J. C. Gluckman, J.-C. Chermann, and L. Montagnier. 1984. Selective tropism of lymphadenopathy associated virus (LAV) for helperinducer T lymphocytes. Science 225:59-63.

20. Koenig, S., H. E. Gendelman, J. M. Orenstein, M. C. Dal Canto, G. H. Pezeshkpour, M. Yungbluth, F. Janotta, A. Aksamit, M. A. Martin, and A. S. Fauci. 1986. Detection of AIDS virus in macrophages in brain tissue from AIDS patients with encephalopathy. Science 233:1089-1093.

21. Krogstad, D. J., and P. H. Schlesinger. 1987. Acid-vesicle function, intracellular pathogens, and the action of chloroquine against Plasmodium falciparum. N. Engl. J. Med. 317:542-549.

22. Lairmore, M. D., G. Y. Akita, H. I. Russell, and J. C. DeMartini. 1987. Replication and cytopathic effects of ovine lentivirus strains in alveolar macrophages correlate with in vivo pathogenicity. J. Virol. 61:4038-4042.

23. Munn, R. J., P. A. Marx, J. K. Yamamoto, and M. B. Gardner. 1985. Ultrastructural comparison of the retroviruses associated with human and simian acquired immunodeficiency syndromes. Lab. Invest. 53:194-199.

24. Narayan, O., and L. C. Cork. 1985 . Lentiviral disease of sheep and goats: chronic leukoencephalomyelitis and arthritis. Rev. Infect. Dis. 7:89-98.

25. Narayan, O., S. Kennedy-Stoskopf, D. Sheffer, D. E. Griffin, and J. E. Clements. 1983. Activation of caprine arthritis-encephalitis virus expression during maturation to macrophages. Infect. Immun. 41:67-73.

26. Narayan, O., J. S. Wolinsky, J. E. Clements, J. D. Strandberg, D. E. Griffin, and L. C. Cork. 1982. Slow virus replication: the role of macrophages in the persistence and expression of visna viruses of sheep and goats. J. Gen. Virol. 59:345-356.

27. Navia, B. A., and R. W. Price. 1987. The acquired immunodeficiency syndrome dementia complex as the presenting or sole manifestation of human immunodeficiency virus infection. Arch. Neurol. 44:65-69.

28. Nicholson, J. K. A., G. D. Cross, C. S. Callaway, and J. S. McDougal. 1986. In vitro infection of human monocytes with human T lymphotropic virus type III/lymphadenopathy-associated virus (HTLV-III/LAV). J. Immunol. 137:323-329.

28a.Orenstein, J. M., and F. Jannotta. 1988. Human immunodeficiency virus and papovavirus infections in acquired immunodeficiency syndrome: an ultrastructural study of three cases. Hum. Pathol. 19:350-361.

29. Palmer, E., C. Sporborg, A. Harrison, M. L. Martin, and P. Feorino. 1985. Morphology and immunoelectron microscopy of AIDS virus. Arch. Virol. 85:189-196.

30. Peluso, R., A. Haase, L. Stowring, M. Edwards, and P. Ventura. 1985. A Trojan horse mechanism for the spread of visna virus in monocytes. Virology 147:231-236.

31. Popovic, M., and S. Gartner. 1987. Isolation of HIV-1 from monocytes but not lymphocytes. Lancet ii: 916 .

32. Quinn, T. C., J. M. Mann, J. W. Curran, and P. Piot. 1986 AIDS in Africa: an epidemiologic paradigm. Science 234:955963.

33. Schidlovsky, G. 1977. Structure of RNA tumor viruses, p. 189245. In R. C. Gallo (ed.), Recent advances in cancer research: cell biology, molecular biology, and tumor virology, vol. 1. CRC Press, Boca Raton, Fla.

34. Serwadda, D., N. K. Sewankambo, J. W. Carswell, A. C. Bayley, R. S. Tedder, R. A. Weiss, R. D. Mugerwa, A. Lwegaba, G. B Kirya, R. G. Downing, S. A. Clayden, and A. G. Dalgleish. 1985 Slim disease: a new disease in Uganda and its association with HTLV-III infection. Lancet ii:849-852.

35. Steinman, R. M., I. S. Mellman, W. A. Muller, and Z. A. Cohn. 1983. Endocytosis and the recycling of plasma membrane. J. Cell Biol. 96:1-27.

36. Tajima, M., H. Nakajima, and Y. Ito. 1969. Electron microscopy of equine infections anemia virus. J. Virol. 4:521-527.

37. Tschachler, E., V. Groh, M. Popovic, D. L. Mann, K. Konrad, B. Safai, L. Eron, F. diMarzo Veronese, K. Wolff, and G. Stingl. 1987. Epidermal Langerhans cells-a target for HTLV-III/LAV infection. J. Invest. Dermatol. 88:233-237.

38. Wahl, L. M., I. M. Katona, R. W. Wilder, C. C. Winter, B. Haraoui, I. Scher, and S. M. Wahl. 1984. Isolation of human mononuclear cell subsets by counterflow centrifugal elutriation (CCE). I. Characterization of B-lymphocyte-, T-lymphocyte-, and monocyte-enriched fractions by flow cytometric analysis. Cell. Immunol. 85:373-383.

39. Wiley, C. A., R. D. Schrier, J. A. Nelson, P. W. Lampert, and M. B. A. Oldstone. 1986. Cellular localization of human immunodeficiency virus infection within the brains of acquired immune deficiency syndrome patients. Proc. Natl. Acad. Sci. USA 83:7089-7093. 